\title{
Use of Liming and Incidence of Diseases in Sugarcane
}

\author{
José Manoel Ferreira de Lima Cruz \\ Federal University of Paraíba, Agricultural Sciences Center, Rod. PB 079, 12, Areia, \\ Paraíba, Brazil \\ E-mail: cruz.jmfl@gmail.com
}

\begin{abstract}
Manoela Gomes da Cruz (Corresponding author)
Federal University of Paraíba, Agricultural Sciences Center, Rod. PB 079, 12, Areia, Paraíba, Brazil

E-mail: manoelacruz.petro@gmail.com

Lucilo José Morais de Almeida

Federal University of Paraíba, Agricultural Sciences Center, Rod. PB 079, 12, Areia, Paraíba, Brazil

E-mail: lucilojose@ hotmail.com
\end{abstract}

Edson de Souza Silva

Federal University of Paraíba, Agricultural Sciences Center, Rod. PB 079, 12, Areia, Paraíba, Brazil

E-mail: eddson_ss@ @otmail.com

Djalma Euzébio Simões Neto

Federal Rural University of Pernambuco, Carpina Sugarcane Experimental Station, Rua Ângela Cristina C. Pessoa de Luna, S/N, Carpina, Pernambuco, Brazil E-mail: djalmasimoesneto@gmail.com

Willams José de Oliveira

Federal Rural University of Pernambuco, Carpina Sugarcane Experimental Station, Rua Ângela Cristina C. Pessoa de Luna, S/N, Carpina, Pernambuco, Brazil 
E-mail: willamsoliveira9@gmail.com

\author{
Guilherme Silva de Podestá \\ Federal University of Paraíba, Agricultural Sciences Center, Rod. PB 079, 12, Areia, \\ Paraíba, Brazil \\ E-mail: guilherme@cca.ufpb.br \\ Fabio Mielezrski \\ Federal University of Paraíba, Agricultural Sciences Center, Rod. PB 079, 12, Areia, \\ Paraíba, Brazil \\ E-mail: mfabio@cca.ufpb.br
}

Received: May 25, 2021 Accepted: June 30, $2021 \quad$ Published: July 17, 2021

doi:10.5296/jas.v9i3.18869

URL: https://doi.org/10.5296/jas.v9i3.18869

\begin{abstract}
This study aimed to evaluate the incidence of red rot, brown leaf spot, and smut in ten sugarcane genotypes during two consecutive cycles, in the absence and presence of limestone. The experimental design consisted of randomized blocks with four replications, in the presence and absence of liming in the following sugarcane genotypes: G1 (RB002754), G2 (RB021754), G3 (RB041443), G4 (RB863129), G5 (RB93509), G6 (RB951541), G7 (RB962962), G8 (RB992506), G9 (SP79-1011), and G10 (VAT90-212) for genotype x environment interaction. The lowest incidences of red rot were observed in G3 (RB041443), G4 (RB863129), G8 (RB992506), and G9 (SP79-1011) for plant cane, and in G3 (RB041443), G4 (RB863129), G5 (RB93509), G8 (RB992506), and G9 (SP79-1011) for ratoon. All genotypes were susceptible to Colletotrichum falcatum, but limestone reduced its incidence in G3 (RB041443), G6 (RB951541), and G10 (VAT90-212) during the first growth cycle, and in G1 (RB002754), G2 (RB021754), G5 (RB93509), G6 (RB951541), G7 (RB962962), and G10 (VAT90-212) in the ratoon crop. Liming also reduced the incidence of brown leaf spot in G4 (RB863129), G6 (RB951541), and G9 (SP79-1011) in plant cane and G6 (RB951541) and G7 (RB962962) in the ratoon crop. Only the G9 genotype (SP79-1011) showed an incidence of smut. The genotypes had different incidence levels of red rot, brown leaf spot, and smut diseases, which varied in the presence of limestone. Limestone use reduced disease incidence as a function of genotype and cutting cycle.
\end{abstract}

Keywords: Cercospora longipes, Colletotrichum falcatum, Saccharum officinarum, Sporisorium scitaminae, limestone 


\section{Introduction}

Since diseases evolve from pathogen-host-environment interactions and vary with the region, the importance of sugarcane diseases in each environmental condition is difficult to classify (Borém et al., 2017). Primary diseases such as smut (Sporisorium scitaminae) and red rot (Colletotrichum falcatum), as well as secondary such as brown leaf spot (Cercospora longipes), can lead to high losses in sugarcane yield; therefore, the behavior of improved genotypes against these pathogens must be understood (Silva et al., 2014; Mielezrski \& Lopes, 2020).

Breeding contributes to developing plant varieties with more desirable traits such as pest and disease resistance, easy environmental adaptation, and higher yield. In this regard, sugarcane is one of the most advanced crops, since currently hybrid cultivars with agronomic, productive, and phytosanitary traits of economic and human interests predominate in the consumer market (Bezerra et al., 2018).

Smut is a disease found in all Brazilian producing regions and may lead to losses of up to $100 \%$ in susceptible varieties (Silva et al., 2014; Mielezrski \& Lopes, 2020). It can be identified by a black appendix, known as a whip, at the plant apex, which arises after pathogen penetration at the base of buds and new leaves. This appendix results from changes in the stem apical meristem and has from a few centimeters to one meter in length. The structure releases a mass of black powdery teliospores that are spread through the crop (Mielezrski \& Lopes, 2020).

In Brazil, red rot is a disease related to Diatraea saccharalis damages, which is known as sugarcane borer, facilitating the pathogen penetration into plant tissues (Pannuti et al., 2013). Early lesions are beige and surrounded by a red halo, progressing to brownish-red, with more severe symptoms in crops on excessively wet soils.

Regarding brown leaf spot, spots resulting from infection can be noticed even on dry leaves. They have an oval shape and dark red color with a yellow halo, present on both leaf surfaces, sporulating and spreading spores by wind, rain, and dew (Mielezrski \& Lopes, 2020).

Soil acidity influences the development of the foregoing diseases. In this sense, liming is an effective means of stimulating root growth in sugarcane crops, increasing water and nutrient uptake area. This, in turn, improves pest and disease tolerance and $\mathrm{Ca}^{2+}$ and $\mathrm{Mg}^{2+}$ supply in plants. Liming also increases organic matter mineralization, which increases nutrient availability to plants. Besides, soil physical properties benefit from increased aggregation, reducing the risk of compaction (Pauletti et al., 2014; Silva et al., 2011; Stadnik et al., 2019).

Given the importance of screening new sugarcane genotypes for disease tolerance and liming benefits, this study aimed to evaluate the incidence of red rot, brown leaf spot, and smut in ten sugarcane genotypes for two consecutive cycles, with and without liming. 


\section{MIMacrothink}

\section{Materials and Methods}

\subsection{Location, Time, and Environment}

Experiments were conducted at the experimental farm Chã de Jardim, from March 2017 to May 2018 (plant cane) and August 2018 to October 2019 (ratoon). The area belongs to the Federal University of Paraíba (UFPB) and is in the city of Areia, in the microregion of Brejo Paraibano, Paraíba State - Brazil (6 $6^{\circ} 58^{\prime}$ S, 35 $42^{\prime}$ W, 574.62-m altitude). According to the Gaussen bioclimatic classification, the 3DTH northeastern sub-dry bioclimate predominates in the study area, with an average annual rainfall of about $1.400 \mathrm{~mm}$. Whereas, under the Köppen classification, the regional climate is $A s^{\prime}$, which is stands for hot and humid, with autumn-winter rains. Figure 1 shows the meteorological data during the study period.

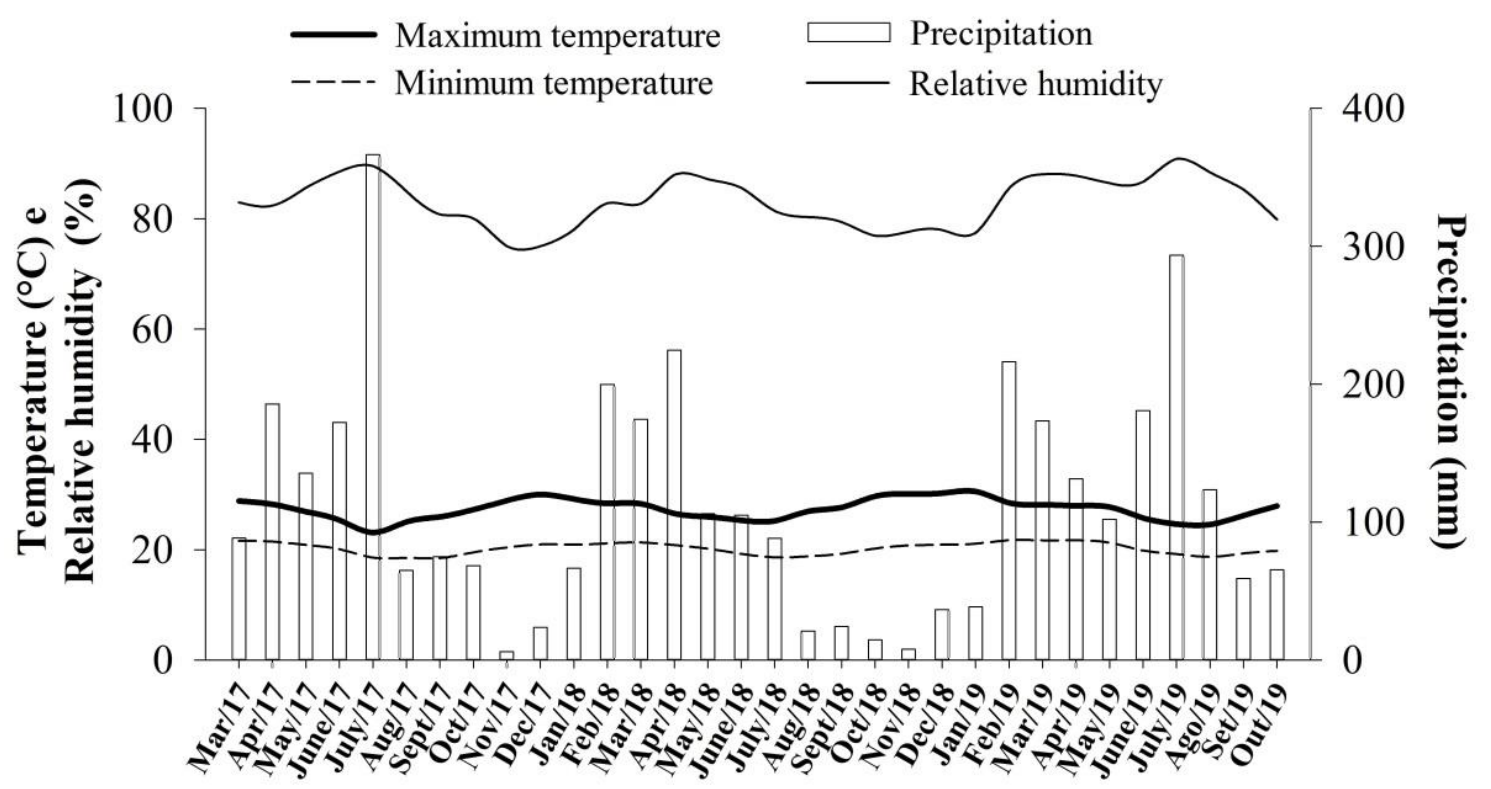

Figure 1. Maximum and minimum air temperature, accumulated precipitation, and average relative air humidity from 2017 to 2019, in the city of Areia, Paraíba State, Brazil

The soil in the experimental area is classified as a sandy loam Regosol (Neossolo Regolítico Psamítico típico, Brazilian Soil Classification System). Simple soil samples were collected at a depth of $0-20 \mathrm{~cm}$ before the experiment was set up for chemical analysis (Table 1). Afterwards, limestone was applied according to the recommendations for the state of Pernambuco (Cavalcanti, 2008).

The soil correction was carried out using dolomitic limestone, with a relative total neutralization power of $62 \%$, to reach a $\mathrm{pH}$ of 6.0 and base saturation (V\%) of $70 \%$. For treatments with limestone, plant cane and ratoon crops received limestone applications of 4.5 and $2.8 \mathrm{t} \mathrm{ha}^{-1}$, respectively. Plant cane fertilization was performed with $90 \mathrm{~kg} \mathrm{ha}^{-1} \mathrm{~N}$ (urea), $120 \mathrm{~kg} \mathrm{ha}^{-1} \mathrm{~K}_{2} \mathrm{O}$ (potassium chloride), and $120 \mathrm{~kg} \mathrm{ha}^{-1} \mathrm{P}_{2} \mathrm{O}_{5}$ (simple superphosphate). Half of the $\mathrm{N}$ and $\mathrm{K}$ sources were applied before planting and a half at 90 days after planting (DAP) 
as topdressing. Phosphorus source was applied $100 \%$ before planting. After the first growth cycle, the ratoon crop received topdressing at 90 days, using the same $\mathrm{N}, \mathrm{P}$, and $\mathrm{K}$ sources as in the first cycle $\left(280,150\right.$, and $130 \mathrm{~kg} \mathrm{ha}^{-1}$, respectively).

Table 1. Soil chemical characteristics of the experimental area. Areia, Paraíba State, Brazil.

\begin{tabular}{|c|c|c|c|}
\hline & $\begin{array}{l}\text { Before sugarcane } \\
\text { planting (2017) }\end{array}$ & $\begin{array}{l}\text { After the first cut, } \\
\text { with limestone } \\
(2018)\end{array}$ & $\begin{array}{l}\text { After the first cut, } \\
\text { without limestone } \\
(2018)\end{array}$ \\
\hline $\mathrm{pH}$ in water $(1: 2.5)$ & 4.8 & 6.02 & 5.72 \\
\hline $\mathrm{P}\left(\mathrm{mg} \mathrm{dm}^{-3}\right)$ & 2.4 & 1.22 & 1.04 \\
\hline $\mathrm{K}^{+}\left(\mathrm{mg} \mathrm{dm}^{-3}\right)$ & 28.4 & 28 & 57.3 \\
\hline $\mathrm{Na}^{+}\left(\mathrm{cmol}_{\mathrm{c}} \mathrm{dm}^{-3}\right)$ & 0.05 & 0.11 & 0.14 \\
\hline $\mathrm{H}^{+}+\mathrm{Al}^{3+}\left(\mathrm{cmol}_{\mathrm{c}} \mathrm{dm}^{-3}\right)$ & 5.49 & 5.85 & 8.08 \\
\hline $\mathrm{Al}^{3+}\left(\mathrm{cmol}_{\mathrm{c}} \mathrm{dm}^{-3}\right)$ & 0.1 & 0 & 0 \\
\hline $\mathrm{Ca}^{2+}\left(\mathrm{cmol}_{\mathrm{c}} \mathrm{dm}^{-3}\right)$ & 0.81 & 3.73 & 3.03 \\
\hline $\mathrm{Mg}^{2+}\left(\mathrm{cmol}_{\mathrm{c}} \mathrm{dm}^{-3}\right)$ & 0.3 & 2.09 & 1.75 \\
\hline $\mathrm{SB}\left(\mathrm{cmol}_{\mathrm{c}} \mathrm{dm}^{-3}\right)$ & 1.23 & 6.21 & 5.53 \\
\hline $\mathrm{CEC}\left(\mathrm{cmol}_{\mathrm{c}} \mathrm{dm}^{-3}\right)$ & 6.72 & 12.07 & 13.58 \\
\hline $\mathrm{OM}\left(\mathrm{g} \mathrm{kg}^{-1}\right)$ & 36.72 & 24.27 & 26.83 \\
\hline
\end{tabular}

P, K, and Na: Mehlich extractor; SB: Sum of exchangeable bases; $\mathrm{H}+\mathrm{Al}$ : $0.5 \mathrm{M}$ calcium acetate extractor, $\mathrm{pH}$ 7.0; CEC: cation exchange capacity; $\mathrm{Al}, \mathrm{Ca}$, and $\mathrm{Mg}$ : $1 \mathrm{M} \mathrm{KCl}$ extractor; OM: organic matter, Walkley-Black.

\subsection{Treatments and Evaluations}

The experiments were carried out in a randomized block design and split-plot arrangement, with four replications. Treatments consisted of liming presence and absence, and the following sugarcane genotypes G1 (RB002754), G2 (RB021754), G3 (RB041443), G4 (RB863129), G5 (RB93509), G6 (RB951541), G7 (RB962962), G8 (RB992506), G9 (SP79-1011), and G10 (VAT90-212). The genotype G9 (SP79-1011) was used as a susceptibility standard. The total area of the experiment was $3292.8 \mathrm{~m}^{2}$. Each subplot was composed of four 6-m-long furrows (20-30 cm in depth) spaced $1.2 \mathrm{~m}$ apart, totaling a useful area of $21.6 \mathrm{~m}^{2}$. Sixteen sugarcane buds were planted per linear meter.

Incidences of brown leaf spot (Cercospora longipes), red rot (Colletotrichum falcatum), and smut (Sporisorium scitaminae) were analyzed at the end of each crop cycle (at 450 days). The total number of plants was determined by counting all plants in the middle rows of each plot, discarding the borders. Then, symptomatic plants were counted by visual inspection, obtaining the total number of sick plants per plot. Leaves were collected from all plots for laboratory analyses and proof of the causal agent. The leaves were transported in kraft paper bags to the Laboratory of Phytopathology (LAFIT) of the UFPB and placed in a humid chamber for 24 to 48 hours to induce sporulation. The pathogens were identified in an optical microscope and stereoscope, using specialized literature (Seifert et al., 2011). Equation (1) 
was used to estimate pathogen incidence after their confirmation.

$$
\text { Incidence }(\%)=\frac{\mathrm{TNSP}}{\mathrm{TNP}} \times 100
$$

wherein: TNSP is the total number of symptomatic plants and TNP is the total number of plants, with results expressed as a percentage of symptomatic plants.

\subsection{Statistical Analysis}

The statistical analysis was performed using the software $\mathrm{R}$ Core Team (https://www.R-project.org/, 2019), with results being subjected to analysis of variance (ANOVA) separately for each period. The Tukey test was performed at $5 \%$ probability to compare means between genotypes with and without limestone application.

\section{Results and Discussion}

Red rot incidence was lower in G3 (RB041443), G4 (RB863129), G8 (RB992506), and G9 (SP79-1011) for treatments with and without limestone in the first growth cycle. Moreover, when evaluated separately, G3 (RB041443), G6 (RB951541), and G10 (VAT90-212) were influenced by liming, showing reduced red rot incidence (Figure 2A). 

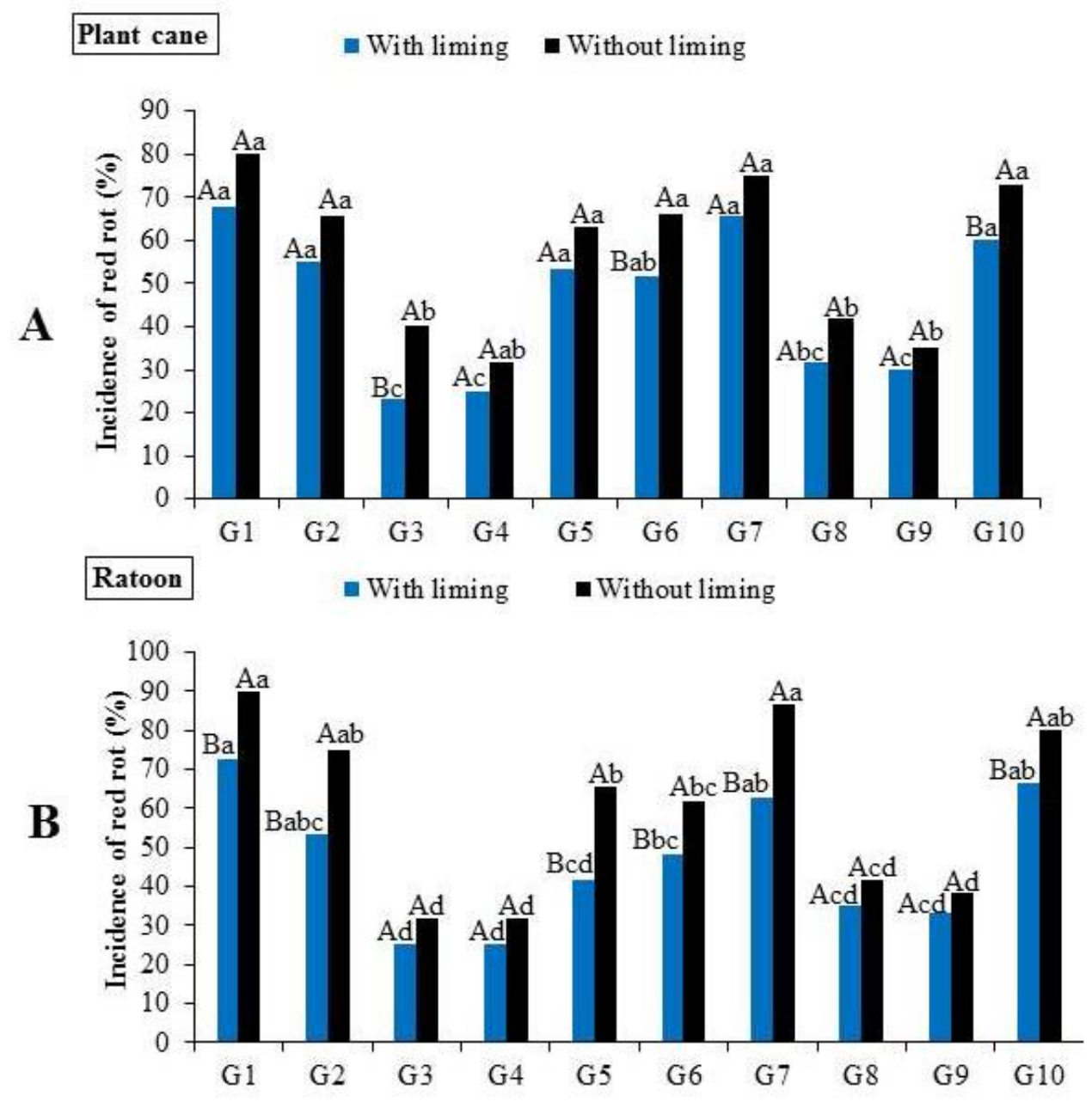

Figure 2. Red rot incidence in sugarcane genotypes in plant cane (A) and ratoon (B) with and without limestone application. Sugarcane genotypes: G1 (RB002754), G2 (RB021754), G3 (RB041443), G4 (RB863129), G5 (RB93509), G6 (RB951541), G7 (RB962962), G8 (RB992506), G9 (SP79-1011), and G10 (VAT90-212). Uppercase letters compare a single genotype with and without limestone. Lowercase letters compare all genotypes with and without limestone

Stadnik et al. (2019) observed that higher pathogen tolerance can be achieved through nutritional balance, increasing potential growth, development, and yield of plants by adjusting their metabolism. In our study, such infection tolerance could be observed in G3 (RB041443), G6 (RB951541), and G10 (VAT90-212) (Figure 2A), which had lower incidences in the presence of limestone. This may be due to better soil chemical properties after limestone application such as higher $\mathrm{pH}, \mathrm{Ca}^{2+}, \mathrm{Mg}^{2+}, \mathrm{SB}$, and $\mathrm{CEC}$ values (Table 1), improving conditions for root growth and development. In this sense, Sousa et al. (2018) observed that low pH levels impair sugarcane root growth (Aquino et al., 2015), directly interfering with soil pest tolerance.

During the plant cane cycle, G3 (RB041443), G4 (RB863129), G5 (RB93509), G8 
(RB992506), and G9 (SP79-1011) showed lower red rot incidences when received limestone application. By contrast, in the absence of liming, G3 (RB041443), G4 (RB863129), G8 (RB992506), and G9 (SP79-1011) had lower disease incidences and were not influenced by limestone when evaluated in isolation (Figure 2B).

According to Lenz et al. (2011) and Stadnik et al. (2019), nutrients can induce changes in plant growth patterns, altering cuticular, epidermal, and cell wall structures. Plant nutrition also changes silicification, suberization, lignification degrees and stimulates the production of inhibitory or repellent substances. Therefore, plant tolerance or resistance to pathogen infection can be increased. Likewise, Borges et al. (2020) reported that highly acidic soils reduce plant nutritional efficiency, which requires soil $\mathrm{pH}$ correction to improve crop performance.

For Cury et al. (2014) and Pauletti et al. (2014), topsoil base saturation increases when liming is performed in no-tillage systems, maintaining plants with homogeneous root masses during growth. In this sense, Sousa et al. (2018) observed that high soil acidity can reduce the sugarcane root system by up to $70 \%$, impairing plant performance.

Roots are the most important components for ratoon crop regeneration and establishment. They directly interfere with plant tolerance to soil pests; therefore, plant root mass must be adequate for necessary functions (Aquino et al., 2015). Pauletti et al. (2014) observed chemical changes within the $0-10 \mathrm{~cm}$ soil layer of an Oxisol under no-tillage after six years of liming, showing increased $\mathrm{Ca}^{2+}$ and $\mathrm{S}^{2-}$ contents and reduced $\mathrm{Al}^{3+}$ saturation, progressing to $20 \mathrm{~cm}$ in depth.

Overall, liming did not affect brown leaf spot incidence in plant cane. But, when assessed separately, it reduced in G4 (RB863129), G6 (RB951541), and G9 (SP79-1011) with liming (Figure 3A). Brown leaf spot was present in all genotypes, with incidence ranging from 20 to $70 \%$ during both growth cycles (Figures $3 \mathrm{~A}$ and $3 \mathrm{~B}$ ). 


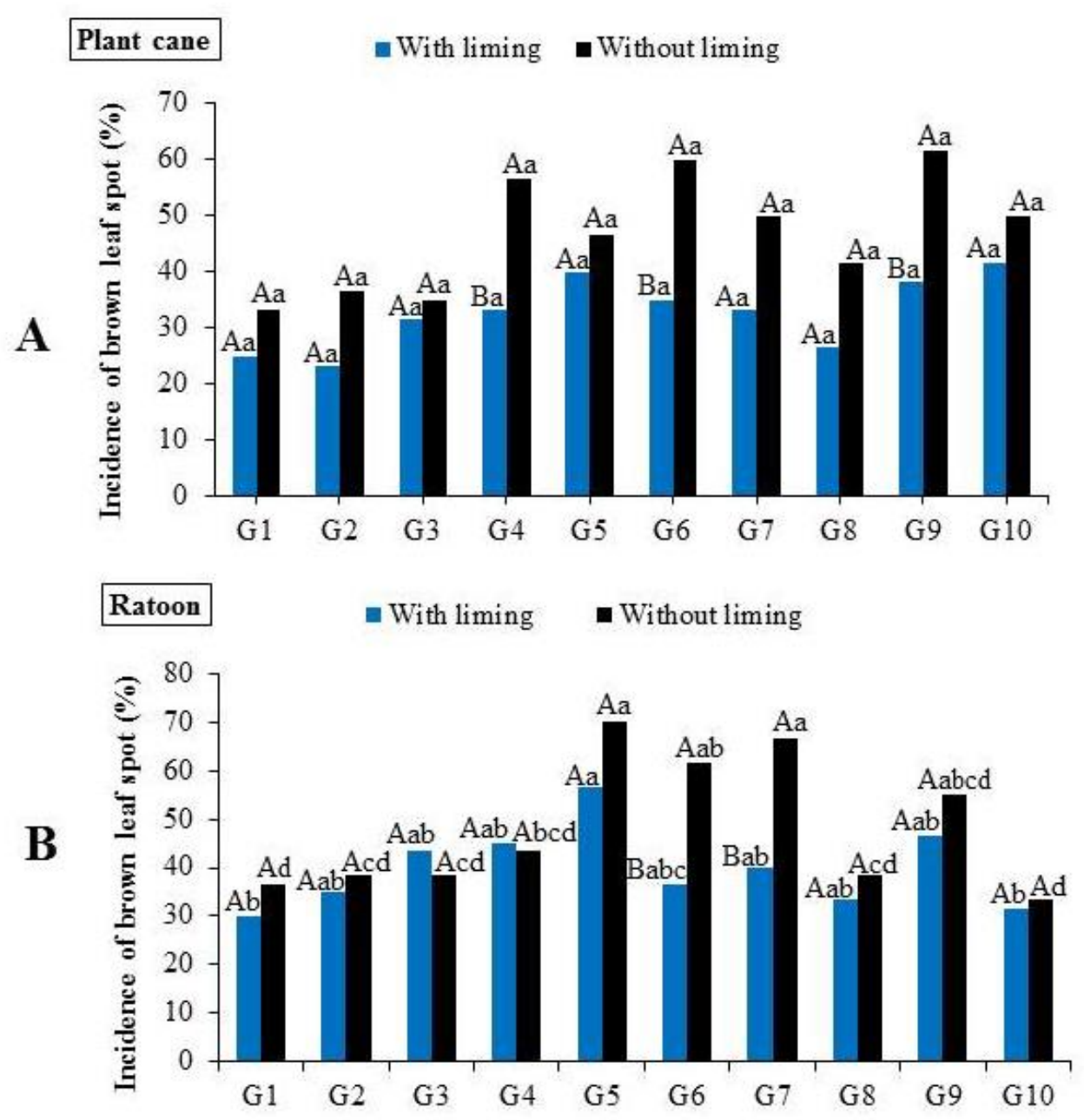

Figure 3. Brown leaf spot incidence in sugarcane genotypes in plant cane (A) and ratoon (B) with and without limestone application. Sugarcane genotypes: G1 (RB002754), G2 (RB021754), G3 (RB041443), G4 (RB863129), G5 (RB93509), G6 (RB951541), G7 (RB962962), G8 (RB992506), G9 (SP79-1011), and G10 (VAT90-212). Uppercase letters compare a single genotype with and without limestone. Lowercase letters compare all genotypes with and without limestone

The genotypes G2 (RB021754), G3 (RB041443), G4 (RB863129), G5 (RB93509), G6 (RB951541), G7 (RB962962), G8 (RB992506), and G9 (SP79-1011) in ratoon crop in limed treatments had the highest brown leaf spot incidence rates. It was also observed for G5 (RB93509), G6 (RB951541), G7 (RB962962), and G9 (SP79-1011) in non-limed treatments. Furthermore, liming only reduced the incidence of this disease in G6 (RB951541) and G7 (RB962962) (Figure 3B).

Liming promotes several benefits such as $\mathrm{pH}$ elevation, availability of nutrients and bicarbonate $\left(\mathrm{HCO}_{3}^{-}\right)$and hydroxyl $\left(\mathrm{OH}^{-}\right)$ions. These, in turn, neutralize toxic elements such as $\mathrm{Al}^{3+}$ and $\mathrm{H}^{+}$, improving sanity, yield, and hence final product quality (Gonçalves et al., 2011; Pauletti et al., 2014; Stadnik et al., 2019). Gypsum and vinasse also increase $\mathrm{pH}, \mathrm{V} \%$, and contents of $\mathrm{Ca}^{2+}, \mathrm{Mg}^{2+}$, and $\mathrm{SO}_{4}{ }^{2-}$, therefore reducing $\mathrm{Al}^{3+}$ in the soil (Carvalho et al., 
2013; Crusciol et al., 2014). The highest $\mathrm{Ca}^{2+}$ and $\mathrm{Mg}^{2+}$ concentrations can be obtained by using limestones of metamorphic and sedimentary origin (Cazotti et al., 2019).

Another factor of high importance is limestone particle size. For Gonçalves et al. (2011) and Viadé et al. (2011), it is one of the most important factors when choosing limestones since smaller particles speed up reaction and dissolution compared to coarser ones. However, the residual effect of finer particles is shorter in the soil compared to the coarse ones that last for years.

Liming improved $\mathrm{pH}, \mathrm{SB}, \mathrm{CEC}, \mathrm{Ca}^{2+}$, and $\mathrm{Mg}^{2+}$ in both production cycles (Table 1). Moreover, some genotypes stood out for tolerance to pathogens, reinforcing the importance of correcting soil acidity, making nutrients available to plants.

The relative air humidity from March 2017 to October 2019 was around 80\%, with precipitation in all months (Figure 1). This might have contributed to pathogen spreading and hence disease incidence in all genotypes since low temperatures and high humidity benefit the occurrence of disease (Marin \& Nassif, 2013). However, although environmental conditions were favorable to pathogen dissemination and development in sugarcane cultivation, some genotypes stood out with lower disease incidence when liming was performed.

Nine genotypes showed tolerance to smut (Sporisorium scitaminae), as they were not affected in both cycles regardless of the limestone application. However, only the genotype G9 (SP79-1011) showed incidences of smut in both growth cycles, but liming decreased it (Figures 4A and 4B). Thus, liming contributed to reducing disease incidence, benefiting genotype growth, development, and hence yield. For Stadnik et al. (2019), nutrients provide beneficial morphological, anatomical, and chemical composition changes, increasing plant resistance to pathogen attacks (Lenz et al., 2011). 


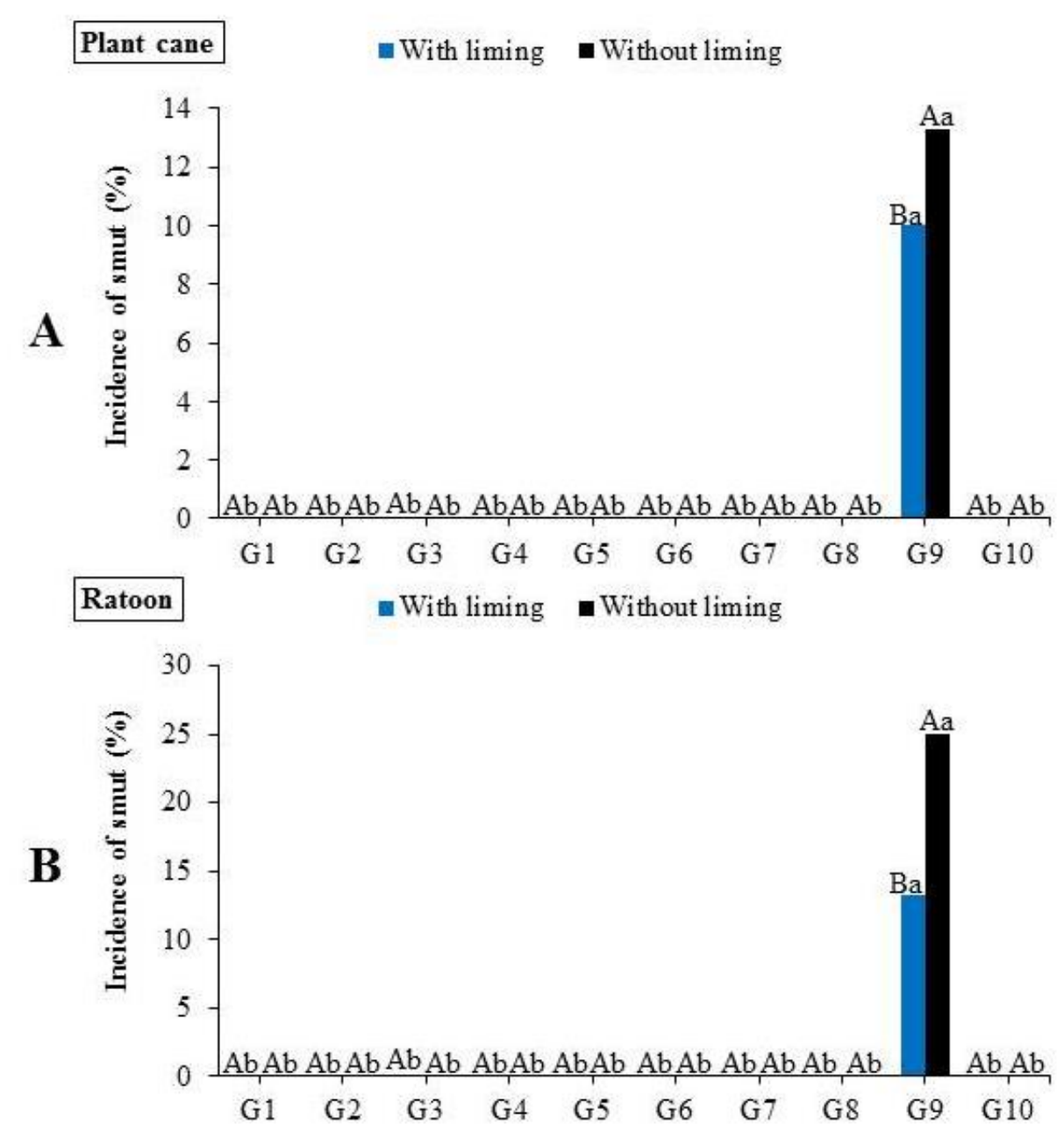

Figure 4. Smut incidence in sugarcane genotypes in plant cane (A) and ratoon (B) with and without limestone application. Sugarcane genotypes: G1 (RB002754), G2 (RB021754), G3 (RB041443), G4 (RB863129), G5 (RB93509), G6 (RB951541), G7 (RB962962), G8 (RB992506), G9 (SP79-1011), and G10 (VAT90-212). Uppercase letters compare a single genotype with and without limestone. Lowercase letters compare all genotypes with and without limestone.

The inclusion of new genotypes in sugarcane fields is an alternative that can provide several benefits, such as induced resistance, barrier effect against the spread of spores, and less susceptibility to initial inoculation. This, therefore, limits the amount of susceptible tissue and potential for pathogen increase, thus delaying epidemics in the field (Stadnik et al., 2019).

We found that almost all genotypes were tolerant to smut except for G9 (SP79-1011), which is used as a standard in the region. In this sense, from a phytopathological view, all other genotypes have the potential to be introduced, either alone or associated with other genotypes.

Plant breeding has developed genotypes with desirable agronomic traits regarding disease 
tolerance, evidencing its importance in the agricultural sector. Moreover, soil correction proved to be of paramount importance for some genotypes to improve tolerance to diseases, enhancing their defense potential when well-nourished.

\section{Conclusions}

The analyzed genotypes showed different incidence rates of the diseases red rot, brown leaf spot, and smut, varying with the presence or absence of liming and cutting cycle.

Liming reduced incidence rates of red rot, brown leaf spot, and smut, depending on genotype and cutting cycle.

Only the genotype G9 (SP79-1011) was susceptible to smut Sporisorium scitaminae, but liming reduced its incidence in both growth cycles.

\section{References}

Aquino, G. S., Medina, C. C., Porteira Junior, A. L., Santos, L. O., Cunha, A. C. B., Kussaba, D. A. O, ... Santiago, A. D. (2015). Sistema radicular e produtividade de soqueiras de cana-de-açúcar sob diferentes quantidades de palhada. Pesquisa Agropecuária Brasileira, 50(12), 1150-1159. https://doi.org/10.1590/S0100-204X2015001200004

Bezerra, J. D. C., Ferreira, G. D. G., Oliveira, M. W., Campos, J. M. S., Andrade, A. P., \& Nascimento Júnior, J. R. S. (2018). Cana-de-açúcar: Melhoramento genético e suas finalidades forrageiras. Nucleus Animalium, 10(2), 131-147. https://doi.org/10.3738/21751463.3518

Borém, A., Miranda, G. V., \& Fritsche-Neto, R. (2017). Melhoramento de plantas (7 ${ }^{\text {a }}$ ed.). Viçosa, MG: UFV.

Borges, C. E., Cazetta, J. O., Sousa, F. B. F., \& Oliveira, K. S. (2020). Aluminum toxicity reduces the nutritional efficiency of macronutrients and micronutrients in sugarcane seedlings. Ciência $\quad e \quad$ Agrotecnologia, 44, e15120. https://doi.org/10.1590/1413-7054202044015120

Carvalho, J. M., Andreotti, M, Buzetti, S., \& Carvalho, M. P. C. (2013). Produtividade de cana soca sem queima em função do uso de gesso e vinhaça. Pesquisa Agropecuária Tropical, 43(1), 1-9. http://dx.doi.org/10.1590/S1983-40632013000100001

Cavalcanti, F. J. A. (2008). Recomendações de adubação para o Estado de Pernambuco: segunda aproximação ( $3^{\mathrm{a}}$ ed.). Recife, PE: Instituto Agronômico de Pernambuco.

Cazotti, M. M., Costa, L. M., \& Cecon, P. R. (2019). Biogenic, sedimentary, and metamorphic limestone: a comparative characterization of soil amendment. Revista Ceres, 66(1), 63-71. https://dx.doi.org/10.1590/0034-737x201966010009

Crusciol, C. A. C., Foltran, R. R., Bagiotto, O., McCray, J. M., \& Rossetto, R. (2014). Efeitos da aplicação superficial de silicato de cálcio-magnésio e gesso na fertilidade do solo e produtividade da cana-de-açúcar. Revista Brasileira de Ciência do Solo, 38(6), 1843-1854. https://dx.doi.org/10.1590/S0100-06832014000600019 
Cury, T. N., Maria, I. C., \& Bolonhezi, D. (2014). Biomassa radicular da cultura de cana-de-açúcar em sistema convencional e plantio direto com e sem calcário. Revista $\begin{array}{lllll}\text { Brasileira de Ciência do } & \text { Solo, } & 38(6), & 1929-1938 .\end{array}$ https://doi.org/10.1590/S0100-06832014000600027

Gonçalves, J. R. P., Moreira, A., Bull, L. T., Crusciol, C. A. C., \& Villas Boas, R. L. (2011). Granulometria e doses de calcário em diferentes sistemas de manejo. Acta Scientiarum. Agronomy, 33(2), 369-375. https://doi.org/10.4025/actasciagron.v33i2.3659

Lenz, G., Costa, I. F. D., Arrué, A., Coradini, C., Dressler, V. L., \& Mello, P. A. (2011). Severidade de doenças e manutenção da área foliar verde em função da aplicação de micronutrientes e fungicidas em trigo. Summa Phytopathologica, 37(2), 219-124. https://doi.org/10.1590/S0100-54052011000200006

Marin, F., \& Nassif, D. S. P. (2013). Mudanças climáticas e a cana-de-açúcar no Brasil: Fisiologia, conjuntura e cenário futuro. Revista Brasileira de Engenharia Agrícola e Ambiental, 17(2), 232-239. https://doi.org/10.1590/S1415-43662013000200015

Mielezrski, F., \& Lopes, G. N. (2020). Cultivo de Cana-de-açúcar na Paraíba (p. 100-119). João Pessoa, PB: UFPB.

Pannuti, L. E. R., Baldin, E. L. L., Gava, G. J. C., Kolln, O. T., \& Cruz, J. C. S. (2013). Danos do complexo broca-podridão à produtividade e qualidade da cana-de-açúcar fertirrigada com doses de nitrogênio. Pesquisa Agropecuária Brasileira, 48(4), 381-387. https://doi.org/10.1590/S0100-204X2013000400005

Pauletti, V., Pierri, L., Ranzan, T., Barth, G., \& Motta, A. C. V. (2014). Efeitos em longo prazo da aplicação de gesso e calcário no sistema de plantio direto. Revista Brasileira de Ciência do Solo, 38(2), 495-505. https://doi.org/10.1590/S0100-06832014000200014

Seifert, K.; Morgan-Jones, G.; Gams, W.; \& Kendrick, B. (2011). The genera of Hyphomycetes. Utrecht, NL: CBS-KNAW Fungal Biodiversity Centre.

Silva, G. S., Alcântara Neto, F., Leite, R. R., Silva, K. C., Monteiro, M. M. S., \& Oliveira, M. A. M. (2014). Ocorrência do carvão da cana-de-açúcar nos Estados do Piauí e Maranhão. Summa Phytopathologica, 40(2), 187. https://doi.org/10.1590/0100-5405/1947

Silva, T. R. B., Lemos, L. B., \& Crusciol, C. A. C. (2011). Produtividade e características tecnológicas de cultivares de feijão em resposta à calagem superficial em plantio direto. Bragantia, 70(1), 196-205. https://doi.org/10.1590/S0006-87052011000100026

Sousa, F. B. F., Cazetta, J. O., Nascimento, S. S. (2018). As diferentes respostas de genótipos de cana-de-açúcar a múltiplos estresses. Ciência e Agrotecnologia,42(5), 527-539. https://dx.doi.org/10.1590/1413-70542018425020718

Stadnik, M. J., Velho, A. C., \& Zorrilla, S. E. (2019). Desenvolvimento Sustentável na produção Agroalimentar. Florianópolis, SC: UFSC.

Viadé, A., Fernández-Marcos, M. L., Hernández-Nistal, J., \& Alvarez, E. (2011). Efeito do 


\section{Macrothink}

Journal of Agricultural Studies

ISSN 2166-0379 2021, Vol. 9, No. 3

tamanho de partícula do calcário sobre os teores de $\mathrm{Ca}, \mathrm{Mg}$ e $\mathrm{K}$ no solo e em plantas de pasto.

Scientia Agricola, 68(2), 200-208. https://doi.org/10.1590/S0103-90162011000200010

\section{Copyright Disclaimer}

Copyright for this article is retained by the author(s), with first publication rights granted to the journal.

This is an open-access article distributed under the terms and conditions of the Creative Commons Attribution license (http://creativecommons.org/licenses/by/4.0/). 